\title{
Viewpoint
}

\section{Forest Grazing: Past and Future}

\author{
BARBARA H. KOSCO AND JAMES W. BARTOLOME
}

\begin{abstract}
Livestock have grazed western forests since the 1850 's. Policy changes with the inception of government regulation and the end of the free open range brought profound changes in the livestock industry. With increasing demands for timber, recreation and wildlife, grazing began to decline in importance as a use of National Forest ranges. Yet, livestock grazing on forest range is critical to yearlong operations of the ranchers who use them. With proper management livestock can be increasingly important not only as meat and fiber producers, but as part of all land management on national ranges.
\end{abstract}

Livestock have been an integral as well as controversial part of forest range use for over 100 years. Current controversy over grazing on forest lands is best understood in the context of historical use. Using California as an example, problems with overstocking, range deterioration, animal distribution, and public attitudes toward grazing can be traced from the gold rush days of the 1850 's, through inception of the National Forests and Forest Service in the early 1900's, to today's grazing policy as affected by increasing timber, recreation and wild life demands. Grazing has been a major past use of the National Forests, and despite current controversies will continue to be a use in the foreseeable future.

\section{Early Grazing Use}

Cattle ranching was the first industry in California (Burcham 1956). The tranquil, pastoral activity characteristic of Spanish and Mexican ranching in California was transformed with discovery of gold on the American River on January 24, 1848 . While livestock had previously been valued almost entirely for their hides, tallow and wool, suddenly a market for meat was created. Livestock production expanded from coastal regions south of San Francisco to the Central Valley closer to the source of demand. Cattle poured into central California from Mexico, Texas, the Midwest, and southern California in attempt to meet the booming demand for beef (Table 1). Burcham (1956) noted that despite the high demand for slaughter cattle and problems with drought, cattle numbers grew phenomenally between 1850 and 1860 leading to heavily overstocked ranges.

The decade $1850-1860$ saw a shift from open range livestock production in the Central Valley to concentration of operations around stable water supplies. Homestead laws of the 1860's encouraged settlement of arable areas of the West. Many ambitious stockmen took advantage of the law to acquire as many waterholes as possible, realizing they could control and graze large areas that would otherwise be unusable due to lack of water (Voigt

Authors are of the Department of Forestry and Resource Management, University of California, Berkeley, CA 94720.
1976). In California, much of the arable land in the Central Valley was put into agriculture. With increased settlement and introduction of barbed wire, fence laws placing responsibility for restraining animals on the livestock owner put an end to free open range in the Central Valley. Stockmen began to drive cattle to the mountains to take advantage of green summer forage and good water supplies not available at lower elevations (Talbot and Cronemiller 1961).

The sheep industry in California, like the cattle industry, began with the Spanish missions and enjoyed a tremendous boom with the gold rush in the 1850-60's. Great flocks of sheep were driven into California via overland trails (Table 1). Migratory sheep grazed the western Sierra Nevada as part of a yearly pattern from 1865 to 1905 , when the travel routes were limited by regulations following the establishment of the National Forests.

Conflicts between stockmen developed during the 1860 's as competition for the public commons at all elevations increased (Heady and Vaux, 1969). Sheepmen were first to take advantage of range forage on high Sierran meadows and meadow composition still reflects the effects of overuse (Burcham 1956). Conflicts over use of the range continued through the 1880's and 1890's. As the choicest ranges dwindled with increased numbers of settlers and declining productivity, a "bigger is better" philosophy, which prevails so broadly today, developed among stockmen on remaining rangelands (Voigt 1976). The phenomenal growth of cattle numbers carried with it a weakness that was to prove fatal, however (U.S.F.S 1936). Cattle ranching was based on a transplanted

Table 1. Livestock populations in California, 1850-1977.

\begin{tabular}{lrrr}
\hline \hline Year & Beef cattle & Sheep & $\begin{array}{c}\text { Animal units of } \\
\text { range stock }\end{array}$ \\
\hline 1850 & 253,599 & 17,574 & 257,114 \\
1860 & 999,836 & $1,099,002$ & $1,217,436$ \\
1870 & 497,349 & $2,768,187$ & $1,050,986$ \\
1880 & 451,941 & $4,152,349$ & $1,282,411$ \\
1890 & $1,048,795$ & $2,475,140$ & $1,543,823$ \\
1900 & 659,660 & $2,563,353$ & $1,194,081$ \\
1910 & $1,609,693$ & $2,417,477$ & $2,120,871$ \\
1920 & $1,229,086$ & $2,400,151$ & $1,732,268$ \\
1930 & 825,224 & $4,083,728$ & $1,658,448$ \\
1940 & 965,239 & $1,707,422$ & $1,318,972$ \\
1950 & $1,107,646$ & $2,056,663$ & $1,528,642$ \\
1960 & $1,800,000$ & $1,500,000$ & $2,100,000$ \\
1970 & $2,200,000$ & $1,200,000$ & $2,500,000$ \\
1977 & $3,636,000$ & $1,113,000$ & $3,800,000$ \\
\hline
\end{tabular}

Source: U.S. Census reports. Agricultural Statistics. 1978. USDA. 
Mexican culture that included no fences, corrals, or supplemental feed. With no gauge of how forages could stand up, speculation ran wild. Grazing lands were stocked far beyond their sustainable capacity and as numbers continued to increase, bad weather and human errors worked to bring disaster (Voigt 1976). The bust came when weakened forage combined with overstocking, blizzards, and drought. Cattle died in great numbers. The boom/ bust phenomena of the 1880's and 1890's characterized the cattle industry, though the situation was aggravated by increased numbers of sheep and the new practice of fencing the range. When disaster struck the cattle couldn't freely roam to avoid storms and search for food. Cattle instead of grass had come to be regarded as the raw resource (U.S. Forest Service 1936). By 1900 stockmen began to realize that control of the range was the only answer. Early vigilante efforts to control the range eventually gave way to government control.

\section{Regulation by the Forest Service}

1860 to 1900 was a time of exploitation of the nation's natural resources. The public was slow to become aware that these resources were not inexhaustible. Timber and water were the first resources to arouse the largely Eastern public's attention. "Cut and get out" timber barons were stripping the forests of the East. Timber cutting was visually obvious, unlike the insidious loss of forage production. Eventually a public cry to stop abuses to the forests resulted in passage of the Forest Reserve Act of 1891. Whatever benefits came to forage through these conservation efforts did so largely as a by-product of action intended to prevent forest destruction (Voigt 1976).

The Forest Reserve Act was a threat to both the livestock and timber industry because the Act prohibited use of the Reserves. Yet, without an administrative organization to prevent trespass, unrestricted use continued. In 1897, Congress acted to provide for administration of the Forest Reserves. The Forest Service was charged to both protect the forests and waters of the nation and allow reasonable use (Roth 1901). Great pains were taken to harmonize grazing with these primary purposes (Jardine and Anderson 1919). Grazing regulations were established to protect, develop and improve the forage resource while encouraging dependent range operations.

The infant Forest Service faced conflicting demands for conservation and production. Local economies were highly dependent on livestock grazing forest forage, yet many of the ranges were overstocked, in poor condition, and declining in productivity. Albert F. Potter, an Arizona stockman, and first Chief of Grazing in the Forest Service, played a critical role in developing early Forest Service grazing policy. In 1913, he stated the problem.

One of the most complex problems connected with the administation of the national forests was that of devising a plan of management by which the forest cover and the watersheds could be adequately protected and all of the lands restored to a normal condition of forage productivity without large permanent reductions in the number of stock grazed or irreparable hardship upon settlers and stockgrowers who were dependent upon forest ranges for the maintenance of their homes (Potter 1913).

Potter understood that the damage to forest ranges from livestock grazing was due to overstocking, grazing too early, or the manner in which the stock were handled-all related to systems of management, not the stock themselves. Initial efforts by the Forest Service were directed at restoration of the range through improved techniques. The task was not easy and is not yet completed.

By mid-1904, however, under Potter's direction a grazing policy emerged. Essentially, management of grazing on National Forests would (1) recognize priority of use, (2) changes in numbers or methods of handling stock would be made gradually, (3) small owners would be given preference in permits, (4) the forage resource would be used to the extent consistent with good forest management, and (5) stockmen would be given a voice in making of rules for management of their stock on the range through
Advisory Boards. The National Forests for the first time, through statutory public land administration, provided local livestock users an assurance of continued use of their ranges.

By 1919, California had approximately 5 million acres in crops, 20 million acres in National Forests, 21 million acres of private decded lands primarily used for grazing, and 54 million acres of unappropriated lands (Kennedy 1919). Grazing was very important, with even much of the area in crops being utilized by grazing animals at some stage of their growth. Large areas of the National Forcsts were as important for grazing as timber production (Kennedy 1919), and a large portion of the 54 million acres of unappropriated lands consisted of the "free" range, controlled by owning of water supplies.

Mountain ranges provided lush summer forage, better water supplies than the foothill ranges, moderate temperatures, and relative freedom from insects and disease forming a vital link to livestock producers. The forage resource consisted primarily of glades, stringer meadows and brush scattered throughout the commercial forest zone. The mountain meadows and stringers were often 10 to 15 times as productive as the open forest, while occupying only a fraction of the grazeable range in forest lands. The Forest Service, from the beginning, had to deal with the difficult problem of determining grazing capacities on this varied but important range type. Grazing capacities often ranged from 1 acre/AUM on good condition ranges (Cronemiller 1953), to as much as 15 to 30 acres/AUM when areas inaccessible to stock such as rocks, dense brush and high elevation were considered (Kennedy 1919; Jardine and Anderson 1919).

At the beginning, not all the National Forest ranges were overstocked (Voigt 1976). The Forest Service was consistently high in its estimates of grazing capacity, however. Steady annual increases in AUM's with a huge increase during World War I reflect the political pressure and optimistic estimates (Table 11). By 1918, the rising AUM's,long season of use and huge increases during the war caused most of the forest range to decline in productivity rather than improve.

Collection of grazing fees, instituted in 1906, brought an economic return greater than or equal to timber sales on the National Forests until about 1930 (Forest Service Annual Reports) (Table 11). Low fees resulted in a tendency of the market to capitalize the free benefits into the value of the dependent private property (Hooper 1967). The grazing privilege became tied to the home base, as the high permit value gave the home base a higher value. After 1910, numerous battles over grazing fees developed between administrative agencies and western livestock interests. Political opposition was strong enough, however, to prevent changes in the fee structure for many years (Heady and Vaux 1969). The foundation of the western economy was mining and livestock grazing on public lands, and practical men of the early Forest Service realized the economic importance of livestock grazing (Roberts 1963; Peffer 1951). This realization helped shape Forest Service range policy. Forest Service personnel recognized the practice of forestry on public lands of the West could not become economically important until more easily accessible private timber had been harvested, and new, closer markets opened up.

One of the biggest problems in utilizing forest range was timing of forage and water supplies. In many areas of the Western Sierra Nevada, for example, water supplies of lower elevation range dried up in the spring before the forage was ready to graze in the forest. Ranchers were often forced to graze on ranges that were critical for winter feed while waiting for the summer range to open up (Smith 1920). Thus stockmen were forced out of business, or to cut down herd size to maintain yearlong feed supplies. The feed situation was further aggravated in the forest range as tree reproduction reduced understory forage supply. Prior to the Forest Service policy instituted in about 1900, ranchers had used fire to keep the forests open. The ranchers felt they were being forced out business and felt that fire and assured water supplies were the only thing that could save them. 
Table 2. Grazing fees, animal numbers, and grazing and timber receipts for the National Forest System (Forest Service Annual Reports of the Chief, 1905-1977).

\begin{tabular}{|c|c|c|c|c|c|c|}
\hline \multirow[b]{2}{*}{ Date } & \multicolumn{2}{|c|}{$\begin{array}{r}\text { Grazing Fees } \\
\text { (dollars/AUM) }\end{array}$} & \multicolumn{2}{|c|}{$\begin{array}{c}\text { Animal numbers } \\
\text { (millions) }\end{array}$} & \multicolumn{2}{|c|}{$\begin{array}{c}\text { National Forest } \\
\text { receipts } \\
\text { (millions of dollars) }\end{array}$} \\
\hline & Cattle & Sheep & Cattle & Sheep & Grazing & Timber \\
\hline 1905 & .05 & .01 & 1.0 & 5.7 & 0.51 & 0.24 \\
\hline 1915 & .10 & .045 & 1.72 & 7.2 & 1.15 & 1.18 \\
\hline 1925 & .13 & .045 & 1.54 & 6.15 & 1.72 & 2.9 \\
\hline 1935 & .08 & .027 & 1.3 & 5.65 & 1.15 & 1.7 \\
\hline 1945 & .25 & .061 & 1.28 & 3.85 & 2.1 & 11.0 \\
\hline 1955 & .37 & .09 & 1.14 & 2.8 & 2.9 & 72.0 \\
\hline 1965 & .46 & .1025 & 1.17 & 2.1 & 3.0 & 130.0 \\
\hline 1975 & 1.10 & 1.10 & 1.38 & 1.45 & 7.7 & 340.0 \\
\hline 1977 & 1.60 & 1.60 & 1.38 & 1.28 & 11.0 & 723.5 \\
\hline
\end{tabular}

The fire policy evolved because Gifford Pinchot, First Chief of the Forest Service, believed control of wildfires was needed to protect and preserve the forests as required by law. Wildfires had turned thou sands of productive acres of forest into brush fields and destroyed stands of valuable timber. Yet, wildfires had also opened up forests, enabling growth of grasses and shrubby species providing livestock forage. Periodic burning had been used by livestock men in the central Sierra Nevada to keep the understory open and encourage livestock feed from the carly 1870's (Bacchi, personal communication). Promiscuous burning by stockmen undermined the Forest Service policy of fire control.

Burning soon became a point of argument. In California, as elsewhere, two camps developed over the fire issue. One side, primarily stockmen, miners and farmers, believed periodic controlled use of fire helped prevent large conflagrations by keeping fuel levels low, while also providing feed for livestock and wildlife. Even a few foresters agreed that the only way to keep fires out of the forest was to use fire and use it often. They felt fire, as a natural process, was entirely consistent with the growth of timber (Ostrander 1902).

Government agencies, both the California State Board of Forestry and the Forest Service, held the opposite view. Fire was identified as the major cause for the existing brushfields in much of the Sierra (Hodge 1904). A fire exclusion policy was instituted and a legal system established to prosecute people who illegally burned on their lands. Fire patrols were established. Forest scientists saw controlled burning as an erroneous practice and a threat to government authority. Marsden Manson, for example, claimed the Sierran Forests were present in spite of burning, not because of it (Manson 1902). Public sentiment was actively enlisted to prevent fires, eventually culminating in Smokey Bear as a national symbol. Large amounts of money went into fire protection, fuelbreaks, fire patrols, and public campaigns to prevent fire.

Though early anti-fire policy was largely politically motivated, the Forest Service also recognized they couldn't allow stockmen and miners to burn as they had in the past and still provide all the multiple uses demanded by the public. The use of prescribed burning is returning to favor as a management tool.

\section{Conflicts over Forest Use}

From the beginning the Forest Service has had to juggle conflicting demands for use of the National Forests. Policy has always been to protect the forests and waters and provide products consistent with conservation goals that provide the greatest good for the greatest number of people in the long run (Jardine and Anderson 1919).

In the 1930's, timber production on the National Forests became increasingly economically desirable. Government policy had evolved toward improving tree species and timber harvesting methods in order to increase timber supply. As income from range forage remained static, support in terms of range conservationists, range research, and money for range improvements began to erode. Many of the early appropriations for range improvements went to regenerate forests rather than rehabilitate range (Voigt 1976). The 1940's brought a policy shifting to place the burden of payment for range rehabilitation from the permittee to the taxpayer. The permittee had always borne the responsibility and cost of range improvements, which furthered the idea of grazing as a "right." Many conservation groups such as the lsaak Walton League stressed the need for government to bear the costs, since grazing was a privilege and only one use of the public's land (Voigt 1976). Foresters, always important, now fully dominated research and management, riding an economic wave of high lumber prices and increased timber cut on the National Forests. In conjunction with this shift, policy also began to emphasize recreation and environmental amenities. Grazing declined in importance, while recreational demand exploded.

Timber, water, and grazing formed a central thread in forest policy for more than a century, yet by the 1970's livestock grazers were left with little political support. Other special interests press demands through their lobbyists for more recreation, wilderness, and wildlife. Dominance in the 11 western states by rural populations, and thus stockmen, in state legislatures and Congress has waned with shifts in population. Yet cattle numbers and beef consumption are at an all-time high. Increased costs of alternative feeds has increased demand for range forage, a reversal of trends started in the 1950's. Unfortunately, such demand now faces strong competition from other newly powerful resource interests. Watershed continues to be an important value, while timber interests hold their own with strong Forest Service support, despite a dwindling land base.

Former broad-based support for the livestock ind ustry has evaporated because of profound changes in our culture and is not likely to return. Stockmen cannot expect unqualified support from government agencies. Yet, the Forest Service still supports livestock grazing as a subordinate use on National Forests as shown by continued requests for more money for range improvements and higher forage productivity through more intensive forest-range management.

The Forest Service wants livestock grazing where minimal conflicts will arise. Forest Service leaders recognize forest grazing is critical to maintenance of year-round operations. Personnel supervising range allotments are still faced with ranchers of the "largest numbers possible" philosophy, however. On the other hand, many stockmen have been, and continue to be, avidly interested in good management and stewardship of the land they have the privilege to graze. The Forest Service is trying to develop a policy to help these "stewards" of the land by providing funds for specific range improvements designated by the permittee.

The future of livestock on Federal lands, forested or not, will likely hinge on detailed inventories of land use capabilities and better management to minimize harmful interactions with conflicting uses. Demands for timber, recreation, secondary homes, and wild life continue to increase, while at the same time the land base for cattle grazing dwindles and costs of production rise. Antigrazing sentiment is growing among environmental preservationists who want no cattle grazing on public lands. Substantive support for the old adage that good range livestock management can benefit other species including wildlife and people must be provided. Livestock should increasingly provide a service, not just as meat and fiber producers but as a part of overall land management. Grazing has been an integral part of the forests of California since statehood, and now with most ranchers and Forest Service personnel alike using good management to improve range condition, livestock grazing on the forest range should continue to be an integral part of our Western heritage.

\section{Literature Cited}

Burcham, L.T. 1956. Historical Geography of the Range Livestock Industry of California. Ph.D. Dissertation. Dept. of Geography, Univ. of 
California, Berkeley. 414 p.

Cronemiller, F.P. 1953. Deerbrush (sweetbirch) in California. U.S.F.S. Region 5. Unnumbered publ.

Heady, H.F., and H.J. Vaux. 1969. Must history repeat? J. Range Manage. 22:209-210.

Hodge, W.C. 1904. Guard the forests from fire. Water and Forest 3:1-2.

Hooper, J.F. 1967. Potential for increases in grazing fees. J. Range Manage. 20:300-304.

Jardine, J.T., and M. Anderson. 1919. Range Management on the National Forests. U.S.D.A. Bull. \#790. 98 p.

Kennedy, P.B. 1919. A study of the forage on the pastures and ranges of California. Univ. of California Agr. Exp. Sta. Proj. \#184B.

Manson, M. 1902. Preserving the forests by fire. Water and Forest 2:5-6.

Ostrander, H.J. 1902. Letter to the San Francisco Call. Water and Forest 2:5.

Peffer, E.L. 1951. The Closing of the Public Domain. Stanford Univ. Press. Stanford, Calif. 372 p.
Potter, A.F. 1913. Administration of grazing in National Forests. Address before the 16th annual convention of the American National Livestock Association. Phoenix, Arizona, January 15th.

Roberts, P.H. 1963. Hoof Prints on the Range. Naylor Co. San Antonio, TX. $151 \mathrm{p}$.

Roth, F. 1901. Grazing in the Forest Reserves. U.S.D.A. Yearbook 1901 p. 333-348.

Smith, E.F. 1920. Grazing Chapter. Supervisor's Annual Working Plan. E Dorado National Forest.

Talbot, M.W., and F. Cronemiller. 1961. Some of the beginnings of range management. J. Range Manage. 14:95-102.

U.S.F.S. Annual Reports of the Chief. 1905-1975.

U.S.F.S. 1936. The Western Range. Senate Document \#199. 620 p.

Voigt, W. Jr. 1976. Public Grazing Lands. Rutgers Univ. Press. N.J. 359 p 